\title{
Pre-school Education Degree students' prior knowledge and perception of digital competence
}

\author{
Gamito, Rakel $^{\mathrm{a}}$; Aristizabal, Pilar ${ }^{\mathrm{b}}$ and Vizcarra, Mariate ${ }^{\mathrm{c}}$
}

${ }^{a}$ Didactic and school organization, University of the Basque Country (UPV/EHU), Spain,

${ }^{\mathrm{b}}$ Didactic and school organization, University of the Basque Country (UPV/EHU), Spain ${ }^{\mathrm{c}}$ Didactics of musical, plastic and body expression, University of the Basque Country (UPV/EHU), Spain

\begin{abstract}
Currently Information and Communication Technologies (ICTs) are necessary for everyday life. That is why digital competence is one of the eight key competences for lifelong learning established by the European Parliament in 2006. In this regard, DigComp is the European framework of digital competence and includes five areas and twenty-one digital subcompentes: Information and data literacy, Communication and collaboration, Digital content creation, Safety and Problem solving. Knowing Pre-School Education Degree students' prior knowledge and perceptions of digital competence is important to strengthen future teachers'digital skills. This work has examined and explored Pre-School Education Degree students' digital competence level. Results have provided concepts and ideas to guide the work to strengthen future teachers' digital skills and to guarantee digitally competent teachers. Pre-School Education Degree students' have good skills in Information and data literacy and Communication and collaboration areas but need training in skills related to Digital content creation, Security and Problem solving.
\end{abstract}

Keywords: Digital competence; DigComp; Pre-School Education Degree, Pre-School Education teachers; Prior Knowledge; Perception. 


\section{Introduction}

Based on Bauman's (2006) metaphor, the current context is liquid and technology is part of that state. Speed of Information and Communication Technology's (ICT) and Internet's development has been extraordinary (Rial, Gómez, Braña, \& Varela, 2014). In a few years being continuously online has become part of the academic, professional and personal everyday life (INTEF, 2016).

Therefore, digital competence is one of the eight key competences for lifelong learning established by the European Parliament and is defined in European Digital Competence Framework, also known as DigComp.

It was on December 18, 2006 when the European Parliament and the Council of the European Union defined, after a long evaluation process, the European framework of reference on lifelong learning. It included the eight key competences "which all individuals need for personal fulfilment and development, active citizenship, social inclusion and employment” (2006/962 / CE, p. 13).

One of the eight key competences identified is digital competence because today ICTs are essential elements in the processes of innovation, expansion and job creation. According to this document, "digital competence involves the confident and critical use of Information Society Technology (IST) for work, leisure and communication” (2006/962 / CE, p. 14).

Subsequently, in order to provide a more robust definition based on scientific evidence and, in turn, create a common language between Education and labor market, the European Commission published in August 2013 DIGCOMP: A Framework for Developing and Understanding Digital Competence in Europe. This project was carried out together with the Institute for Prospective Technological Studies (IPTS) and the Joint Research Center (JCR) to define accurate and official areas and descriptors of digital competence (Ferrari, 2013). Then, it has become the frame of reference for various curriculas, initiatives and/or certificates (INTEF, 2017).

Recently, the updated DICGOMP 2.0: The Digital Competence Framework for Citizens has been published (Vuorikari, Punie, Carretero, \& Van Den, 2016). As in the previous proposal, the new document includes five areas and twenty-one digital subcompetences: Information and data literacy, Communication and collaboration, Digital content creation, Safety and Problem solving (table 1). 
Gamito, R.; Aristizabal, P.; Vizcarra, M.

Table 1. The DigComp Conceptual reference model

Competence areas

Sub-competences

1.1 Browsing, searching and filtering data, information and digital content

1. Information and data literacy

1.2 Evaluating data, information and digital content

1.3 Managing data, information and digital content

2.1 Interacting through digital technologies

2.2 Sharing through digital technologies

2. Communication and collaboration

2.3 Engaging in citizenship through digital technologies

2.4 Collaborating through digital technologies

\subsection{Netiquette}

2.6 Managing digital identity

3.1 Developing digital content

3.2 Integrating and re-elaborating digital content

3. Digital content creation

3.3 Copyright and licences

3. 4 Programming

\subsection{Protecting devices}

4. Safety

4.2 Protecting personal data and privacy

4.3 Protecting health and well-being

4.4 Protecting the environment

5.1 Solving technical problems

5. Problem solving

5.2 Identifying needs and technological responses

5.3 Creatively using digital technologies

5.4 Identifying digital competence gaps

Source: DigComp 2.0: The Digital Competence Framework for Citizens (Vuorikari, Punie, Carretero, \& Van Den, 2016).

Consequently, digital competence is currently an essential educational element. ICTs have the potential to impact on people's thought, action and representation (García del Dujo \& Martín, 2002), but this requires that teachers have "the necessary training in that competence” (INTEF, 2017, p. 5) to use technology in a innovate way (Area, 2008). 
In other words, integrating ICTs in a pedagogical way is a challenge that requires training. Therefore, it is important to know Pre-School Education Degree students' digital competence level to be able to work more effectively and strengthen future teachers'digital skills.

As a consequence, the present work has responded to the following aims:

1. Examine Pre-School Education Degree students' prior knowledge of areas and subcompetences that make up the digital competence according to DigCom..

2. Explore the perception that Pre-School Education Degree students have about their own digital skills according to the different areas proposed by DigComp.

\section{Method}

Examine students' prior knowledge and perceptions is necessary to make a constructive teaching-learning process (Lerner, 1996). In this regard, and because students build knowledge by interpreting their perceptions or experiences (Huber, 2008), this research was based on evidence of productions, verbal interactions, dialogues and answers. All of this was obtained directly and from a practical and reflexive position.

The work was attended by 67 Pre-School Education Degree second grade students (during the 2017/18 academic year at the Education and Sport Faculty of the University of the Basque Country (UPV / EHU) located in Vitoria-Gasteiz (Álava).

Data collection was made, first of all, dividing participants into 20 groups of 3 or 4 members grouped randomly, and subsequently, individually. In the first phase of development, students were asked to define one of the five areas of digital competence according to DigComp: Information and data literacy, Communication and collaboration, Digital content creation, Safety and Problem solving. To do this, students worked cooperatively and based only on their prior knowledge of digital competence.

Next, oral presentation of productions and later collective dialogue were aimed at exploration of associations and meanings, allowing to know what the group involved think or feel, their perceptions, strengths and shortcomings (Krueger, 1991). These productions were compared and completed with DigComp framework to achieve a more detailed perspective on digital competence.

Finally, students' personal digital skills in DigComp subcompetences were assessed by an individual online questionnaire and using a scale from 1 to 5 (1: insufficient; 2: sufficient; 3: good; 4: very good; 5: excellent).

Information obtained was processed individually and jointly. Firstly, answers and assessments of each area were analyzed separately and then they were studied together. 
This has facilitated the interpretation, offering an overview of the set of prior knowledge and perception of digital competence (Barton, 2006).

\section{Results}

The results are organized around the five areas of digital competence included in DigComp framework:

In relation Information and data literacy area, it is where Pre-School Education Degree students involved show high knowledge and say that they have a good command of it (3.37 out of 5). They identify information not only as text, they also give great importance to data in audiovisual format: "information can be obtained thought writing, videos or photographs" (group1 and group 4).

At the same time, future teachers highlight the importance of contrasting sources to confirm the accuracy of searches: "we must verify that the information is reliable and, for that, it is necessary to consult different sources and use trusted sources" (group 4). Students involved believe that the subcompetences referring to Information and data literacy are a great help to, mainly, do academic work: "as students, these subcompetences allow us to find information more quickly and to be able to perform the works in a more precise way" (group 1).

$56.7 \%$ believe that their skill in browsing, searching and filtering information is very good and $37.3 \%$ good. However, perception of digital contents'evaluation competence as well as the storage and recovery competence is lower. There are more those who assess their skill in these subcompetences as good (50.7\%) instead of as very good (37.3\%).

Describing Communication and collaboration area, future teachers involved set aside subcompetences related to engagement, digital identity and/or netiquette to focus only on interaction options, sharing information and/or work in groups: "skills in digital communication and collaboration allows us to interact, share interesting material and work in groups "(group 8). Likewise, this area is defined from a technical point of view. Students mention many tools such as social networks, instant messaging applications and/or learning platforms (virtual classrooms) instead of the multiple strategies used in interaction and collaboration processes to describe Comunication and collaboration competence.

The description matches the results of the students' personal perception concerning the area. Interacting through digital technologies and sharing digital information and contents are the subcompetences that have obtained best results. Nearly half (47.8\%) believe that their skills in communicate and/or share digitally is very good and, even, part (16.4\%) assess it as 
excellent. On the contrary, assessment of netiquette is low. $19.4 \%$ have rated their skill in the Internet's behavior standards as sufficient and $10.4 \%$ as insufficient.

In Digital content creation area, something similar happens. To describe the area, students involved only list subcompetences directly related to creation and they obviate copyright, licenses and/or programming: "creating audio-visual content, texts... for teaching and sharing" (group 11). In addition, students focus creation more on tools than on strategies and the majority of tools that they mention are basic commercial office automation packages.

Likewise, while assessment of subcompetences related to development and integration of digital content is good (60.45\%) or very good (27.45\%), a certain lack of training regarding copyright and programming is perceived. Much of future teachers involved indicate sufficient skill in licenses and programming (29.9\% and $20.9 \%$, respectively) and even a part rate it as insufficient (4.5\% and $7.5 \%$, respectively).

Security also has many deficiencies. Although its definition is one of the most complete and general perception of skill in the area is good (3.00 out of 5), Security is the only area that has obtained insufficient assessment in all its subcompetences. Many students believe that they are only sufficiently skilled protecting their devices (17.9\%), personal data and digital identity (13.4\%), health (20.9\%) and environment (17.9\%). Between 1.5\% and 3\% affirm that their skill in security measures is insufficient and they indicate formation about the Internet security as improvement proposals.

Results of Problem solving area also indicate not a good perception. Describing the area, students involved focus on resolution of technical problems and, in many cases, on digital security: "we must know how to solve technical problems such as viruses or attacks and it is important to establish rules of use and security "(group 19). In turn, they do not include or mention any subcompetence related to innovation and/or creativity and it is quite high the percentage (between $25.4 \%$ and $32.8 \%$ ) of future teachers that assess their skill in problem solving only as sufficient.

\section{Discussion and conclusions}

In general, Pre-school Education future teachers' knowledge and assessment of digital competence of are good (3.16 out of 5) but there are differences between areas and/or subcompetences, as in many similar studies.

Pre-School Education Degree students have a great knowledge and high level skill in Information and data literacy (3.37 out of 5) and Communication and collaboration (3.31 out of 5) areas, as Ferrés, Aguaded-Gómez, \& García-Matilla’́s (2012) studies. 
Instead, coinciding with Gabarda, Rodríguez, \& Moreno (2017), future teachers 'knowledge and skills on Digital content creation (3 out of 5), Security (3.25 out of 5) and Problem solving (2.87 out of 5) areas are lower. Students think that they need training session, mostly, on online security.

Likewise, the global vision that future teachers have of digital competence is eminently instrumental (Gutiérrez \& Serrano, 2016). Describing many of the areas, students involved have forgotten strategies to focus on the use of specific tools.

Therefore, it is necessary to develop training proposals aimed at strengthen Pre-School Education Degree students' digital competence in order to guarantee digitally competent teachers. It is important to work skills and strategies related to creative, engaging, safe and responsible use of ICT.

\section{References}

2006/962/CE, Recommendation of the European Parliament and of the Council of 18 December 2006 on key competences for lifelong learning. Offical Journal of the European Union, L394, 18 December 2016.

Area, M. (2008). La innovación pedagógica con TIC y el desarrollo de las competencias informacionales y digitales. Investigación en la escuela, 64, 5-17.

Barton, K. C. (2006). Research methods in social studies education: Contemporary issues and perspectives. Connecticut: IAP

Bauman, Z. (2006). Modernidad líquida. Buenos Aires: Fondo de Cultura Económica.

Ferrari, A. (2013). DIGCOMP: A Framework for Developing and Understanding Digital Competence in Europe. Seville: Joint Research Centre. Institute for Prospective Technological Studies. doi: https://doi.org/10.2788/52966

Ferrés, J., Aguaded-Gómez, I., \& García-Matilla, A. (2012). Digital competence in students of educational degrees. Analysis of future teachers' competence and perception. ICONO 14, 10(3), 23-42. doi: https://doi.org/10.7195/ri14.v10i3.201

Gabarda, V., Rodríguez, A., \& Moreno, M.D. (2017). La competencia digital en estudiantes de magisterio. Análisis competencial y percepción personal del futuro maestro. Educatio Siglo XXI, 35(2), 253-274. doi: https://doi.org/10.6018/j/298601

García del Dujo, A \& Martín, A.V. (2002). Caracterización pedagógica de los entornos virtuales de aprendizaje. Teoría de la educación, 14, 67-92.

Gutierrez, I. \& Serrano, J.L. (2016). Evaluation and development of digital competence in future primary school teachers at the University of Murcia. New approaches in educational research, 15(1), 53-59. doi: https://doi.org/10.7821/naer.2016.1.152

Huber, G. (2008). Aprendizaje activo y metodologías educativas. Revista de Educación, special numer 2008, 59- 81. 
INTEF, Instituto Nacional de Tecnologías Educativas y de Formación de Profesorado (2016). Uso de las tecnologías por niños de hasta 8 años. Un estudio cualitativo en siete países._Retrieved from https://goo.gl/Na7kKt

INTEF, Instituto Nacional de Tecnologías Educativas y de Formación de Profesorado (2017). Common Digital Competence Framework for Teachers. October 20017. Retrieved from https://goo.gl/Aaocqf

Krueger, R. A. (1991). El grupo de discusión: guía práctica para la investigación aplicada. Madrid: Pirámide.

Lerner, D. (1996). La enseñanza del aprendizaje escolar. Alegato contra una falsa oposición. En VV.AA., Piaget-Vigotsky: contribuciones para replantear el debate (pp. 69-117). Buenos Aires: Paidós.

Rial, A., Gómez, P., Braña, T., \& Varela, J. (2014). Attitudes, perceptions and Internet and social networks use among Galician teens. Anales de psicologia, 30, 642-655. doi: http://doi.org/10.6018/analesps.30.2.159111

Vuorikari, R., Punie, Y., Carretero, S., \& Van de Brande, L. (2016). DigComp 2.0: The Digital Competence Framework for Citizens. Luxembourg: Publications Office of the European Union. doi: https://doi.org/10.2791/11517 